\title{
Implementing Population Health and Social Determinants Approaches in Cuba
}

\author{
Nivaldo Linares MD MS PhD
}

Excerpted by the author, translated and reprinted with permission from Revista Cubana de Salud Pública. 2015Jan-Mar;41(1):94-114.

Original available from: $h$ ttp://scielo.sld.cu/scielo.php?pid=S0864-34662015000100009\&script=sci_arttext

\begin{abstract}
This paper discusses integration and implementation of population health and social determinants approaches to the health-disease -care process in the context of ongoing changes to Cuba's health system. Ideas for strengthening the social conceptualization of public health and prioritizing population health actions over those of individual medical care are discussed, with a view to encouraging rethinking of these as social practice. The paper aims to advance new and renewed strategic proposals for change, based on a broad view of public health and a focus on social medicine that favors a popula-
\end{abstract}

\section{INTRODUCTION}

Neither friends nor foes dispute Cuba's achievements in the social and health spheres. The enormous efforts of the Cuban state and National Health System to achieve sustained improvements in health for its population are unquestioned. Cuba's high levels of human development, schooling and life expectancy[1] are well known, as are its achievements in reducing infant mortality; eradicating, eliminating and controlling infectious disease; providing comprehensive coverage and protection against vaccine-preventable diseases; and universal access to health care without discrimination by gender, race/ ethnicity or social position.[2]

$$
\cdots
$$

Today's Cuba faces diverse economic and social challenges.[3] On one hand, there are constraints on development, economic growth and living conditions, in addition to social inequalities within a population with differing perceptions of reality and levels of social awareness. On the other hand, Cuba faces challenges from the global economic crisis and ongoing US blockade thatin recent years, together with other objective and subjective causes, have been analyzed in various social, political and governmental spheres.

Add to this a national demographic panorama characterized by marked and accelerated aging of the Cuban population;[4] a changing health-disease profile with growing predominance and substantive increase in the burden of chronic non-communicable diseases on health services;[5] and the complex public health and epidemiological situation of recent years, with events such as the dengue and cholera epidemics.[6] Other noteworthy factors are deficiencies in medical care provision and implementation of population-level health interventions, health personnel's economic and working conditions, and integration of national health sector activities.

The extent of these realities offers an opportunity for reflection and debate on how existing health systems, when viewed as both tion health perspective and inclusion of a wide range of health determinants. It advances the need to develop or extend debate on the theory and social practice of epidemiology and public health while implementing needed changes in health services and medical care. The paper recommends embarking on technical discussions among all actors and protagonists, not just in the health care system but in the entire health sector, to better integrate and practice a population health approach with social determinants of health.

KEYWORDS Public health, social medicine, collective health, social determinants of health, Cuba

social and cultural systems, should respond with health policies that effectively apply population health, social determinants and social determination in health approaches when redesigning strategies and interventions for better health promotion, disease prevention and broad social participation in the interests of collective health, well-being and life.

\section{POPULATION HEALTH, SOCIAL DETERMINANTS AND SOCIAL DETERMINATION APPROACHES TO HEALTH AND DISEASE}

Given health's inescapable connection to the collective, public and social sphere,[7] public health practices have undergone a succession of evolving movements rooted in shifting articulations between society and the State, which have defined social responses to health needs and problems at each specific juncture. These movements have their origins in historical reference points that have been thoroughly analyzed elsewhere from diverse perspectives.[8-14] The social and historical makeup of health and health systems has given rise to a widely-accepted understanding of health systems as social systems.[15]

The movement that has contributed most to this social concept of health, from its first formulation in the late 18th century to the present, is social medicine (also known as social sciences applied to health, or the social sciences of health). $[9,11,13,16,17]$ The conceptual basis of this school of thought rests on linking the health-disease process and health services to social, political and cultural factors; and the active role of the State in solving health problems.[15,16,18]

The population dimension underlying health explanations and interventions makes a distinction between public health actions and medical or biomedical actions at the individual level. From this perspective, public health as a field of knowledge recognizes the multiplicity of scientific and technical disciplines within it. As a 


\section{Reprint}

sphere of action, public health operates in the space where social actors organize to confront disease and its consequences at the population level.[7]

\section{$\cdots$}

The three main perspectives on the population dimensions and social practice of public health are Health Canada's population health approach,[19] the social determinants of health model of WHO's Commission on Social Determinants of Health, $[20,21]^{25,26}$ and the social determination approach advanced by the Latin American social medicine and collective health movement.[22-24]

The so-called Canadian approach was developed in the mid1970s and widely disseminated throughout Latin America at the end of the 1990s. It makes a clear distinction between population health and the traditional concept of medical care. In the Canadian view, the main differences are that: 1) population health strategies address a broad range of patterns of health determinants, whereas traditional approaches rely on risk and clinical factors linked to specific illnesses; and 2) population health strategies are designed to reach the entire population, whereas medical care is directed at individuals, frequently those already suffering from a health problem.

$\cdots$

As Rojas Ochoa notes: "The 21st century will be the century of applying social sciences to the resolution of health problems." In his view, actions by health systems adopting a population health approach must consider: 1) the comprehensive and interdisciplinary inclusion of all, or nearly all, social determinants of health; 2 ) that the health sector cannot act alone, because most health determinants exist outside its areas of expertise, and require intersectoral action; 3) that public policy is an important tool for population health and cannot be restricted to the health sector only, but must be viewed as healthy public policy; and 4) the need to prioritize research leading to understanding the impacts of social determinants, identifying health inequities, and designing more effective intervention mechanisms.[8]

The social determinants of health model advanced by the WHO Commission on Social Determinants of Health in its 2008 report[21] recognizes the impact on health of the social conditions in which people live and work, in addition to the impacts of context and social processes. This approach recommends acting on the social determinants of health to improve the overall situation and combat inequities in the way health conditions are distributed. Like the European model of social epidemiology, this approach recognizes the existence of two types of social determinants: 1) structural (socioeconomic and political contexts, socioeconomic status); and 2) intermediate (connecting structural factors to health outcomes, and consisting of material circumstances, behavioral and biological elements, psychosocial factors and the health system).[25]

The social determination model proposed at the end of the 1970 s by Latin American social medicine and collective health differs conceptually and methodologically from the social determinants approach. The latter focuses on descriptive analysis of causal relations between the characteristics of different social groups and health problems (identifiable inequalities) and on possible associations among variables of social conditions and health indicators in countries with differing levels of development. It does not subscribe to the theoretical principle that it is necessary to analyze population health conditions taking into account structural components of societies and the concept of social determination of health as the crux of a complex and critical way of thinking about the relationship between society and health.[24,26]

In analyzing population dimensions and social practices in health, Gostin[27] identifies two public health approaches (Figure 1). One is the so-called "limited" approach, which proposes that public health should focus on the study of risk factors (biological, environmental or behavioral) affecting population health. The "broad" approach, in contrast, holds that it is the task of public health to take into account structural conditions (social, economic or cultural) that affect population health.[7] Although widely accepted and predominant, the former offers a more limited way of understanding the social and economic origins of disease, while the latter assigns greater responsibility to public health in addressing the social determinants of health.

Two basic considerations have gained broad currency over recent decades: 1) public health can no longer be limited to

Figure 1: Population dimensions of public health actions

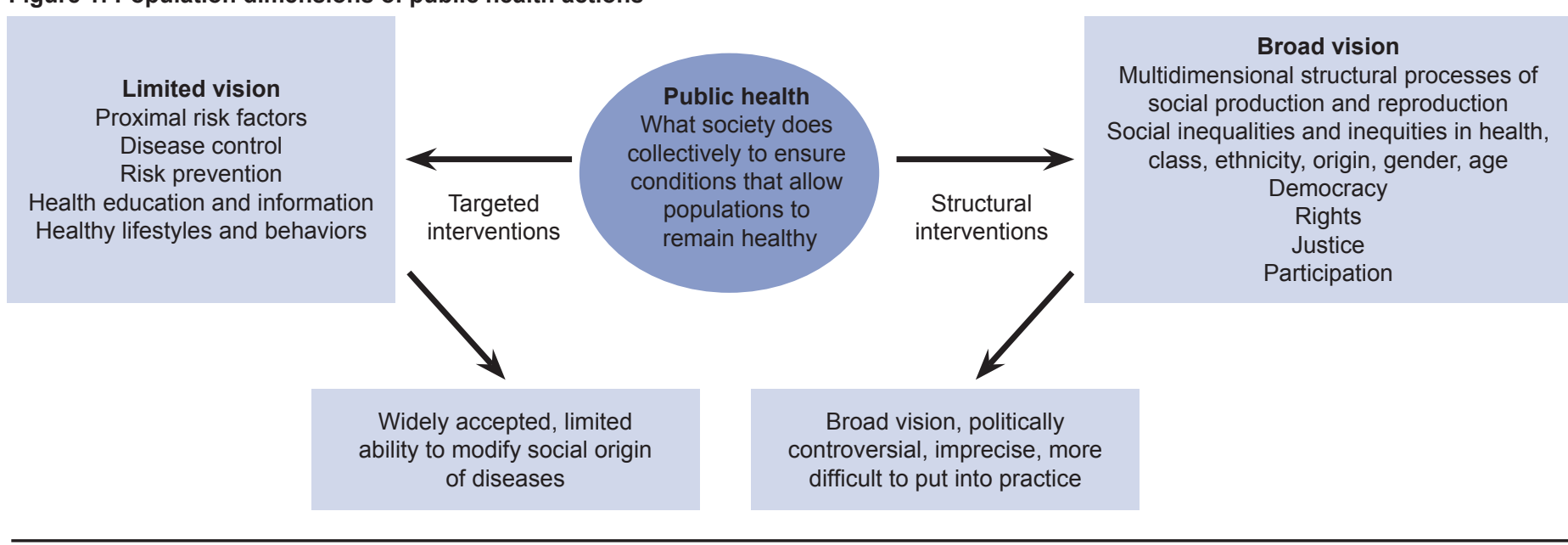


carrying out circumscribed actions based only on the "limited" or "restricted" approach to health and must attempt to overcome the limitations imposed by a view centered on disease and the technical aspects of its functions; and 2) bolstered by the social sciences, and interacting with social, economic and political sciences, analysis and interpretation of (social and health) inequalities are facilitated through a holistic view of health determinants to achieve increasingly effective public and health policies.[28]

Approaches to health and disease: continuity or change? Today, public health exerts enormous influence on the biomedical view of health. But medical schools, research institutes, service providers and institutions responsible for directing health systems continue to give priority to actions at the individual level, especially those linked to disease. Lesser importance is assigned to the population health approach and collective action to generate the living conditions and well-being that favor population health. Disease continues to receive more attention than health, despite accepted understanding that the greatest health gains at the lowest costs are not made through provision of individual medical care.

Well-established ideas of health promotion and disease prevention, interinstitutional cooperation and intersectoral articulation still take a back seat in actual health practice. Unfortunately, the recommendation to prioritize population health actions over individual medical attention as a first step toward design and development of health policies shaped by population health and social determinants is not always heeded when seeking better understanding and development of the technical, political and social dimensions of public health as a social practice.

This necessary change of direction toward explicit adoption of a broad view of public health is not only an ethical, theoretical and practical imperative in the face of palpable social and health inequalities, but also signals engagement with social processes, by creating, adapting and using categories, methods and instruments to observe, measure and compare the public health actions based in this broader vision. In other words, the study and modification of structural processes linked to living conditions, well-being and work to explain social, economic and culture inequalities that must be addressed in order to transform them[29] indicate that national health systems must refocus their colossal endeavors and give priority to considerations concerning life, well-being and health over those of disease and risk.[30]

\section{IDEAS FOR DISCUSSION OF SOCIAL DETERMINATION IN THE PRACTICE OF EPIDEMIOLOGY \\ AND PUBLIC HEALTH}

To envision opportunities for real change in social determination where public health is practiced, this paper presents several ideas meant to stimulate reflection, discussion and generation of proposals to strengthen public health from a holistic vision in its theory and practice of medical care; design and evaluation of policies for health promotion and disease prevention; research; and training of human resources, among other substantive areas. These ideas include:

1. Reconstruct health system functions from an epidemiological approach.
The epidemiological orientation of the health system has two starting-points: first, the acceptance-at least theoretically-that epidemiology is the synthetic discipline in public health; and second, the notion that epidemiological thinking is what introduces the collective interest and communal or public point of view into society's responses to health problems, from the vantage point of permanent inquiry and research into situations that generate or maintain health problems.[31-33]

In Cuba, as elsewhere, the health system's epidemiological orientation has come into question. Some public health professionals, especially epidemiologists, have argued whether public health nationally is grounded in a theory and practice that could be called a Cuban approach (or school) of epidemiology.

Opinions also differ on whether or not the so-called "epidemiological leadership" of the National Health System has responded to the application of the theoretical foundations that, directly or indirectly, support professional practice and actions for health promotion and disease prevention undertaken by formal institutional structures.[33]

It seems obvious that today, as in the past, the idea of the "epidemiological leadership" required by the National Health System has more to do with political will, awareness, organization, social development and overall accessibility and financing of health services than with the conceptual, epistemological and methodological development of epidemiology as a basic public health discipline in academic and research circles and in health care services. We agree with Martínez Calvo,[33] who states that, more than an epidemiological orientation, we are seeing the "bold application of the traditional epidemiological approach, accompanied by the prevailing hegemonic biomedical way of thinking." We believe it is a matter of some urgency to prioritize the real and permanent integration of epidemiology's technical thinking into the strategic and operational activities of the health system and health services at every level.

2. From individual health to collective health: social requirements of health and its determinants as the object of public health.

A broad understanding of the social determinants of health suggests that health services alone are insufficient to understand and transform these determinants, should they become the "new object" of public health. If this notion is accepted, it would be necessary to:

- reformulate the scope of public health, understanding it as encompassing the distribution of health-disease determinants and the interpretations, knowledge and specialized practice around the health of human groups;

- estimate the social requirements of health and its determinants in a way that transcends traditional perspectives of risk, harm, disease and death; and

- make sure efforts to change or transform this "new object" employ tools or instruments coming more from epidemiological than clinical knowledge. Even when the social requirements of health can be reduced to health problems at the population level, they must address the social and environmental conditions that define them, and the instruments employed should emerge from knowledge generated by anthropology, sociology, social psychology, economics, ecology, political science and other fields.[14,17] 
I agree with many authors on the advisability of adopting a broad vision of public health that incorporates macrostructural processes into its analysis and explicitly recognizes the transcendence of social, economic, cultural and environmental determinants of health. I also support giving greater consideration to health and disease profiles than to disease in isolation, and addressing the collective problems of health and death through transformation of social processes that produce inequalities. I support giving priority to political action that links diverse actors, promoting academic spaces for critical thought, and training health professionals with broad vision.[29]

\section{$\ldots$}

3. Expand areas of health knowledge and practice using a sociocultural epidemiological approach.

It is important to point out the centrality of health-disease -care processes within social dynamics and structures, beyond their existence as individual phenomena.[34] This requires reconfiguring the way in which health problems and their determinants are conceptualized, and the theoretical and practical updating of a necessary dialogue between epidemiology and the social sciences. Expanding areas of knowledge and practice in public health, as viewed through the prism of sociocultural epidemiology, would require agreeing to the following precepts:

- Prioritize a holistic approach and restructure epidemiological practice from a theoretical and epistemological perspective, in order to connect the various levels, spheres and factorsincluding structural, social, cultural, biological and ecological ones-that intervene in the explanation of health problems.

- Put into practice a combination of quantitative and qualitative methodological research strategies; advance in the measurement of health-disease-care; and overcome the individualsocial dichotomy in epidemiological analysis and its correlate: the gradual decontextualization of the epidemiological perspective.

- Develop program interventions linked to a sociopolitical vision of health and reformulate a new model of health actions to encompass strategies for medical care, public health interven- tions and health policies, from the perspective and based on the specific characteristics of a target population.

4. Renew the traditional functions of epidemiological practice and public health, and incorporate new ones.

I urge the renewal of traditional functions and incorporation of new ones in the institutional work of epidemiology and public health in order to secure a sustained epidemiological approach to health system and sector practices.

The idea is to explicitly adopt a broad approach to public health in strategies, programs and policies that combine renewed traditional functions and new functions derived from applying the social determinants of health to strategies for intervention on risk, disease and harm, such as those guided by Europe's "Health in All Policies" approach, which includes intersectoral action, community participation and social determination (Figure 2).

5. Maximize the value of health in social and health sector agendas. Public health must promote new experiences that allow for evaluation of its real potential to formulate healthy public policies and incorporate these into the debate between political decision-makers and health managers, as a means of facilitating their adoption and integration into strategic planning processes at every level of the health system.

The underlying principle here is to maximize health gains and reduce as much possible the impact of inequalities among population groups. The key to this is to work effectively by using social determinants of health, undertaking intersectoral action and developing conceptual and methodological principles to evaluate the health impacts of policies, programs and projects, for gradual integration of their outcomes into decision-making.[35]

$$
\cdots
$$

6. Strengthen understanding of gender analysis and its application throughout the health system.

Figure 2: Proposed new and renewed functions for technical areas within Cuba's National Health System institutions

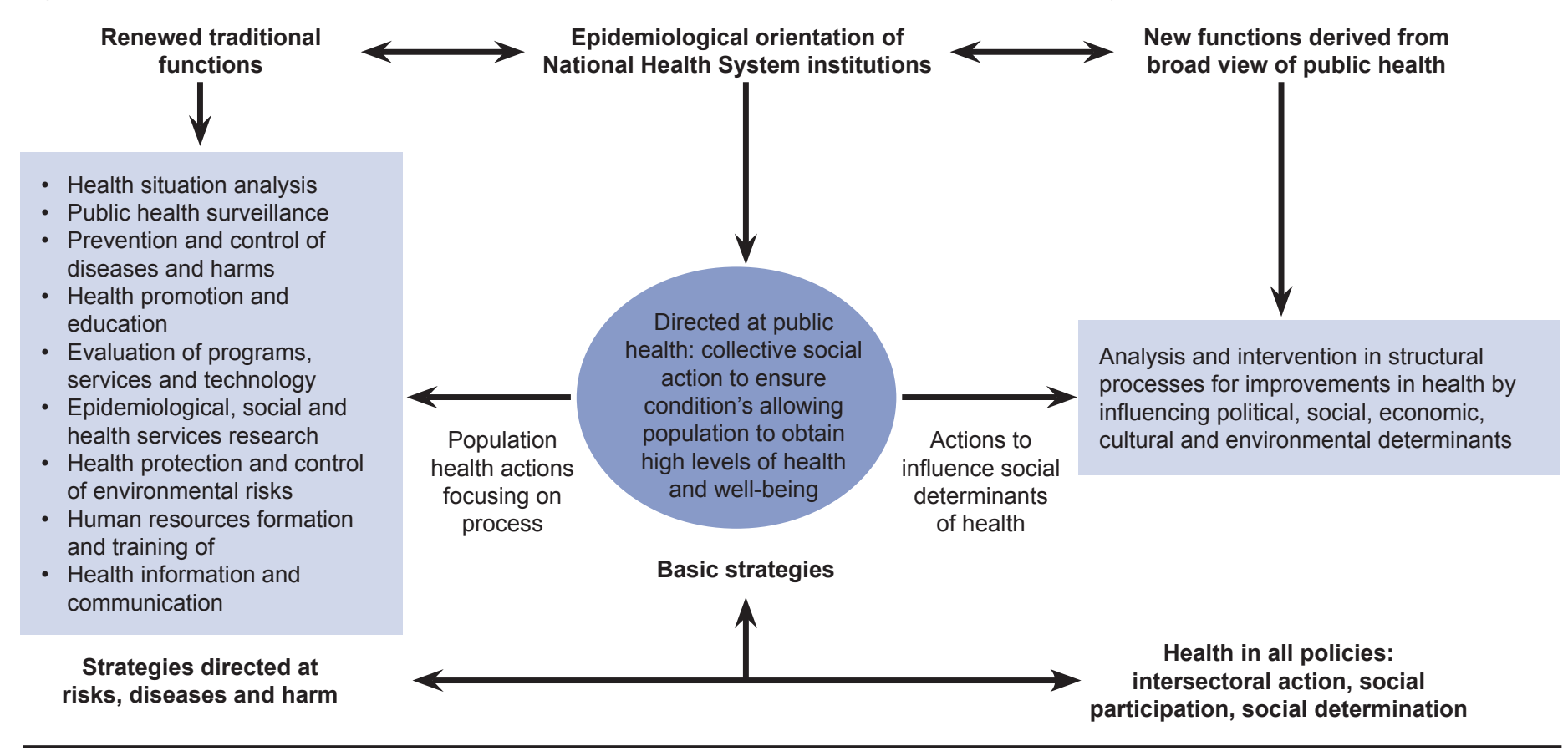


Gender analysis makes visible the power relations and subordination determined by sex differences and relationships between women and men,with a view to differentiating sociocultural from biological constructions. This facilitates better understanding of social and political realities and should be used as an analytical category and as a determinant of health.[36] Gender, like social class, is intrinsic to human organizations, and many sociocultural and historically constructed variables add social dimensions to biological sex differences.[37]

Adopting and strengthening this approach in the conceptualization and social practice of public health makes clear the need to acknowledge differences between men and women when defining health risks and carrying out health measures, as well as in developing and implementing policies and programs to achieve gender equity. This means being aware of the influences of biological, social and cultural structures when studying health problems, since these impact men and women in different ways.

7. Deepen understanding of the complexity paradigm and its application in population health issues.

Many authors in the field of social medicine have called for new paradigms to address diverse research inquiries, especially in epidemiology, health policy analysis and social practice, using dynamic systemic models from the perspectives of complexity theory, micro and macro levels and health system transformation. $[38,39]$

The key may lie in the application of transdisciplinarity, the strategic methodology of complexity, which addresses science's historical materialism by establishing a pragmatic definition of transdisciplinarity as a process, action strategy and mode of practice, as opposed to a characteristic of complex objects or attributes of complexity in relationships among disciplines.[40]

In Cuba, as elsewhere, scientists from various institutions, including the National School of Public Health, give credence to complexity theory, which emerged in the mid twentieth century as a scientific paradigm to "understand the complexity of life" based on a theoretical approach to the study of highly complex objects (such as health) without resorting to their radical reduction. $[41,42]$

\section{$\cdots$}

Adopting complex thinking and complexity science requires a nonlinear holistic, systemic, transdisciplinary understanding of natural, biological and social processes. It fosters knowledge exchange, self-management, cooperation and reciprocity in solidarity from below, with citizen responsibility interconnected with public policies, which creates possibilities for reconstruction of scientific knowledge and its application to social, environmental and human processes, with benefits for constructive projections from the current international context.[43]

$\cdots$

Other ideas for future action for new or revised health policies based on the social determinants of health approach would contribute answers to questions such as: what theoretical and conceptual adjustments to technical, social and health policy does
Cuban public health require? How can we move forward to reformulate the object and practice of our public health endeavors, addressing individual concerns from a new perspective that places the importance of the social at the heart of the collective? How can we institutionalize social and collective thinking as a priority within the National Health System?

\section{STRATEGIC PROPOSALS FOR CHANGE IN EPIDEMIOLOGICAL THINKING AND PRACTICE IN CUBA}

During the first half of 2013, a working group of experienced national and international public health practitioners was convened by the Ministry of Public Health (MINSAP) to formulate strategic proposals for the development of the Hygiene, Epidemiology and Microbiology Area of the National Health System. MINSAP's Working Group to Strengthen Hygiene and Epidemiology 2013 produced an unpublished paper titled: "Strategic Proposal to Strengthen Hygiene, Epidemiology and Microbiology in the Process of Comprehensive Improvements to the National Health System: Program for Action 2013-2016. Hygiene, Epidemiology and Microbiology Area." Havana: MINSAP. Executive Summary, July 2013. pp. 1-27.

The group's technical proposal is based on recognized institutional and technical reference frameworks and analysis of the health situation in the overall health system and the hygiene and epidemiology subsystem, the area charged with conceptual, methodological and operational leadership of population health interventions and services.

... These are the proposed changes:

1. Revitalize epidemiological thinking and practice throughout the National Health System as a necessary part of the social practice of Cuban public health and development of population health services and interventions.

2. Reorient the conceptualization and operation of the Hygiene and Epidemiological Area of the National Health System toward a population health and social determinants of health perspective, and abandon the rigid, vertical and disciplinebased vision that currently governs its operations.

3. Improve the organization, operations and strategic scope of the National Health System's Hygiene and Epidemiological Area by focusing on functions and processes to implement population health services and interventions and the system's epidemiologicalorientation.

Specific objectives underlying the strategies and action areas for development and implementation of these proposals for change were as follows:

1. Redesign the structure and technical functions of the Hygiene and Epidemiological area at all levels of the National Health System.

2. Improve epidemiological practice in all National Health System units and services within a framework of needed renewal and adjustments to the medical care model.

3. Strengthen technical/managerial skills and performance of personnel carrying out functions and technical processes within the Hygiene and Epidemiological Area.

4. Improve and develop the National Health System's health surveillance system. 
5. Monitor, analyze and evaluate population health status.

6. Redesign health promotion and education from an intersectoral, inclusive and participatory approach.

7. Contribute to the development of information and communications for population health in light of new technological and social scenarios.

8. Strengthen performance evaluation of the health system and services at all levels of the National Health System.

To better understand how to effectively integrate population health and social determinants approaches into current public health practice in Cuba, I will cite, by way of example, five proposals from the MINSAP Working Group.

Example 1. Update epidemiological thought and practice to ensure a sustained epidemiological approach in the National Health System.

This would require incorporating into all levels of the health system a focus on priority health problems; evaluation of the clinical-epidemiological approach as applied to services, programs and technologies; development of in-service training; and promotion of research giving priority to the local level; all this with the explicit support of a primary health care strategy.

Updating epidemiological thinking and practice would advance redesign of MINSAP structures, technical areas and provincial and municipal health subsystems based on functions and procedures to ensure implementation of population health interventions as successful as those focused on medical care and disease.

Example 2. Promote renovation and adjustments to the medical care model and its main strategies, including primary health care, to extend application of a population health approach.

This entails incorporating epidemiological and social thinking into medical care within a broad vision of public health, that is, a social determinants of health approach. It means giving priority through the primary health care strategy to promotion and prevention activities that cover the entire population and not just vulnerable groups, as is traditionally the case. It means undertaking the necessary strengthening of health services capacities and infrastructure, constantly updating Cuba's family medicine model, greater availability of appropriate modern technologies, and improvements in clinical practice based on current population health problems, but also taking into account structural processes and ongoing socioeconomic and generational changes. All this must be rooted in the political, ideological and social principles of the Cuban Revolution and its ethical and humanist commitments.

Example 3. Strengthen health situation analysis and the social requirements for health and its determinants at all levels of the health system and health sector.

This involves two interrelated areas of work. The first looks at developing epidemiological practice directed at priority problems derived from monitoring, analysis and evaluation of the health situation, and renewing principles, procedures and techniques to conduct health situation analyses and create intersectoral connections, giving priority to the local level. The second area prioritizes participatory research into solutions for prevalent health problems, their risks and social determi- nants, with priority at the local level, explicitly incorporating health determinants into institutional research and updating the conceptual and methodological foundations for such studies. This would ensure application of findings in designing policies and strategies to target social inequalities and their health impacts.

Example 4. Promote the reformulation, improvement, modernization and development of a national strategy for health surveillance.

This suggests that the health surveillance system should be redesigned and modernized, and its capacity to respond to high-impact epidemiological events strengthened, as should its corresponding subsystems (by level of service and type of institution), giving maximum priority to epidemiological emergencies and public health. This renewal is linked to a health promotion and social determinants of health approach and envisions incorporation of structural dimensions (social, economic, environmental, political and cultural) into the analysis of health-disease-care processes in order to create new and different practices, some of these even contradictory to practices based on natural history of diseases and predominant risks.

Example 5. Propose introduction and development of health impact assessment as a tool in decision making, the formulation of health-related public policies and strengthening of public health.

This involves promoting incorporation of scientific knowledge into decision-making processes at all levels of health system leadership. It implies recognizing the real application of concepts and methods of causal evaluation based on available evidence or new empirical information, in order to link each intervention (in policies, programs, projects and others) to health outcomes. This impact assessment approach to population health is perfectly coherent with the discourse and evidence of social determinants of health and intersectoral work, as apparent in countries where the population health approach and management of social determinants ensure the "health in all policies or health protection in all policies" principle.

$\cdots$

\section{FINAL COMMENTS}

\section{$\ldots$}

The ideas presented here are not meant to ignore or reject prevailing approaches to health and disease, but to reexamine them in light of knowledge and evidence now being systematized about the application of population health and social determinants of health approaches from a vision of social medicine and collective health.

In Cuba's particular case it is advisable to develop a process for technical discussions among all actors and protagonists, not only in the health system but in the entire health sector, about the contents of a strategic proposal for change to revitalize epidemiological thought and practice in Cuban public health generally and in its institutional model (health system and health sector), to better 
integrate and operationalize a population health and social determinants of health approach.

The success of these proposals will require thorough strategic, managerial, technical, social and political understanding of the action areas developed; proven leadership in their oversight and implementation; demonstrated capacity for conciliation, negotiation and coordination among people from diverse disciplines within and outside of the health system; and permanent willingness to keep high on the agenda the priority for Cuba's health system transformation from a broad vision of public health.

$\ldots$

To do this from the perspective of social medicine is to acknowledge the need to better understand the determinants of the health-disease-care process and its complexities. It also requires understanding social determinants' relevance to medical problems and public health, especially their usefulness in analyzing health problems in relation to economic production, social determination and political practice in a specific social and historical context.

Finally, it is necessary to take firm steps to formulate and apply models that promote structural, comprehensive, technical and political perspectives on public health, and to merge methods and techniques from the natural, biological and social sciences, so that technical and political thought and action become an intrinsic part of interventions performed to ensure achievement of the final goal: population health and well-being.

\section{ACKNOWLEDGMENTS}

Thanks go to all professionals convened by MINSAP to participate in the technical discussions and in formulating strategic development proposals for the National Health System's Hygiene, Epidemiology and Microbiology Area. A special thank-you to Prof. Silvia Martínez Calvo for her unflagging commitment to and encouragement of epidemiology and public health in Cuba. - 1 -

\section{REFERENCES}

1. Informe sobre el Desarrollo Humano 2013. El ascenso del Sur: Progreso humano en un mundo diverso. Programa de las Naciones Unidas para el Desarrollo Nueva York: PNUD; 2013.

2. Di Fabio JL. Aniversario 110 de la OPS. Organizaciones Panamericana y Mundial de la Salud (OPS-OMS) en Cuba. La Habana: Museo Nacional de Bellas Artes; 2013

3. Partido Comunista de Cuba. Lineamientos de la política económica y social del Partido y la Revolución. La Habana. 18 de abril del 2011.

4. Proyecciones de la salud pública hasta 2015. La Habana: MINSAP; 2010.

5. Informe Anual Año 2012. La Habana: MINSAP; 2013.

6. Área de Higiene, Epidemiología y Microbiología: Informe Anual Año 2012. La Habana: MINSAP; 2013b.

7. López S, López-Arellano O, Puentes E. Marco General: Concepto de Salud Pública. En: López $S$, Puentes E, editores. Observatorio de la Salud pública en México 2010. México, D. F.: Universidad Autónoma Metropolitana, Unidad Xochimilco; 2011. p. 19-27.

8. Rojas Ochoa F. El componente social de la salud pública en el siglo XXI. Rev Cubana Salud Pública. 2004 [citado 8 Sept 2014];30(3). Disponible en: http://www.scielo .sld.cu/scielo.php?script=sci_arttext\&pid=S0864 -34662004000300008 \&lng $=\mathrm{es}$

9. Nunes ED. Trayectoria de la medicina social en América Latina: elementos para su configuración. En: Franco S, Nunes E, Breilh J, Laurell AC, editores. Debates en Medicina Social. Quito: Organización Panamericana de la Salud/Asociación Latinoamericana de Medicina Social; 1991.

10. La crisis de la salud pública: reflexiones para el debate. Publicación Científica 540. Washington, D. C.: OPS; 1992.

11. Almeida Filho N, Silva Paim J. La crisis de la salud pública y el movimiento de la salud colectiva en Latinoamérica. Cuadernos Médico Sociales. 1999;75:5-30.

12. Waitzkin $\mathrm{H}$, Iriart C, Estrada A, Lamadrid S. Social Medicine Then and Now: Lessons From Latin America. Am J Public Health. 2001;91(10):1592601

13. Iriart $\mathrm{C}$, Waitzkin $\mathrm{H}$, Breilh $\mathrm{J}$, Estrada $\mathrm{A}$, Merhy EE. Medicina social latinoamericana: aportes y desafíos. Rev Panam Salud Publica/Pan Am J Public Health. 2002;12(2):128-36.
14. Silva Paim J. Movimientos en el campo social de la salud. En: Silva Paim J, editor. Desafíos para la Salud Colectiva en el siglo XXI. Buenos Aires: Lugar Editorial; 2011. p. 103-22.

15. Rojas Ochoa F. Teoría y práctica de la medicina social. En: Silva Hernández D, editor. Salud Pública Medicina Social. La Habana: Editorial Ciencias Médicas; 2009. p. 73-97.

16. García JC. Juan Cesar García entrevista a Juan Cesar García. En: Duarte Nunes E, editor. Ciencias Sociales y Salud en America Latina. Tendencias y Perspectivas. Montevideo: OPS/CIESU; 1986. p. 21

17. Silva Paim J. ¿Nueva Salud Pública o Salud Colectiva?. En: Silva Paim J, editor Desafíos para la Salud Colectiva en el siglo XXI. Buenos Aires: Lugar Editorial; 2011. p. 123-36.

18. Galeano D, Trotta L, Spinelli H. Juan César García y el movimiento latinoamericano de medicina social: notas sobre una trayectoria de vida. Salud colectiva. 2011;7(3):285-315

19. Health Canada. Salud de la población. Conceptos y estrategias para las políticas públicas saludables: la perspectiva canadiense. Washington, D.C: OPS; 2000

20. SECRETARIAT Commission on Social Determinants of Health, Towards a Conceptual Framework for Analysis and Action on the Social Determinants of Health. May 5, 2005.

21. Comisión sobre Determinantes Sociales de la Salud. "Subsanar las desigualdades en una generación». Informe final. Ginebra: OMS; 2008.

22. Breilh J. La Determinación Social de la salud "Una Perspectiva Emancipadora de la Investigación y Acción, Basada en la Determinación Social de la Salud». Taller Latinoamericano de Determinantes Sociales de la Salud, 29 de septiembre al 2 de octubre. México, D. F.: ALAMES; 2008.

23. González R. La medicina social ante el reporte de la Comisión sobre los Determinantes Sociales de la Salud. Medicina Social. 2009;4(2):135-43.

24. Eslava JC. Tras las huellas de la determinación. Seminario Interuniversitario de Determinación Social de la Salud. Bogotá: Universidad Nacional de Colombia; 2014.

25. Frenz P. Desafíos en Salud Pública de la Reforma: Equidad y Determinantes Sociales de la Salud. Santiago de Chile: Ministerio de Salud; 2005.

26. Breilh J. La determinación social de la salud como herramienta de transformaciónhacia una nueva salud pública (salud colectiva). Rev Fac Nac Salud Pública. 2013;31(supl 1):13-27

27. Gostin LO. Public health law and ethic. Los Angeles: University of California Press, The Milbank Memorial Found; 2002.

28. López-Arellano O, Blanco-Gil J. Políticas de Salud en México: más policía médica y menos salud colectiva. En: Peña F, León B, editores. La medicina social en México. II Globalización neoliberal. México, D. F.: Consejo Editorial ALAMESMéxico, A.C.; 2008. p. 55-64

29. Closing the gap in generations. Health Equity through action on the social determination of health. Commission on Social Determinants of Health: Final Report. Geneva: WHO; 2008.

30. López-Arellano O, Blanco-Gil J. Determinantes sociales de la salud. Una perspectiva desde la medicina social y la salud colectiva. México, D. F.: Universidad Autónoma Metropolitana, Unidad Xochimilco; 2013.

31. Breilh J. 10 tesis hacia una visión crítica de la determinación social de la vida y la Salud. Conferencia en el Seminario "Rediscutindo a questão da determinação social da saúde», 19-20 marzo. Salvador (Bahía-Brasil): Centro Brasileiro de Estudos de Saúde (CEBES); 2010.

32. Macedo CG. Discurso apertura, documento del Seminario sobre "Usos y Perspectivas de la Epidemiología». Nov 7-10 (Publicación No. PNSP 84-47/1984); Buenos Aires, Argentina: Seminario; 1983.

33. Nájera E. Investigación y desarrollo profesional. Serie Desarrollo de Recursos Humanos, 88. La formación en epidemiología para el desarrollo de los servicios de salud. Washington, D. C.: Oficina Sanitaria Panamericana; 1987.

34. Martínez Calvo S. El enfoque epidemiológico del sistema de salud de Cuba. Rev Brasileira Epidemiología. 1999;2(1 y 2):19-33.

35. Haro JA (coordinador). Epidemiología sociocultural: un diálogoentorno a su sentido, métodos y alcances. Buenos Aires: Lugar Editorial; 2011.

36. Morales-Asencio M, Gonzalo Jiménez E, Martín Santos FJ, Morilla Herrera JC. Salud pública basada en la evidencia: recursos sobre la efectividad de intervenciones en la comunidad. Rev Esp Salud Pública. 2008;82:5-20.

37. Valencia MA. Aportes de los nuevos enfoques para la conformación de la salud publica alternativa. Rev Fac Nac Salud Pública. 2011;29(1):85-93. 


\section{Reprint}

38. Castellanos PL. Avances metodológicos en epidemiología. En: Campinas S. Anais do $1^{\circ}$ Congresso Brasileiro de Epidemiologia: epidemiologia e desigualda de social, os desafios do final do século. Abrasco; 1990. p. 201-16.

39. Almeida-Filho N. The paradigm of complexity: applications in the field of public health. Advisory Committee on Health Research. A Research Policy Agenda for Science and Technology to Support Global Health Development. Ginebra: WHO; 1997.
40. Almeida-Filho N. Complejidad y transdisciplinariedad en el campo de la salud colectiva. Salud Colectiva. 2006;2(2):123-46.

41. RamisAndalia R. Factores de Riesgo vs. Determinantes sociales de la Salud. La Habana: Escuela Nacional de Salud Pública; 2013.

42. Cárdenas ML, Rivas José F. La teoría de la complejidad y su influencia. Rev TeoríaDidáctica Ciencias Sociales. 2004 enero-diciembre:131-41.

43. Cátedra de Complejidad de La Habana, Sección Psicología y Sociedad/Sociedad Cubana de Psi- cología. Encuentro Científico Complejidad 2014: Pensamiento y Ciencias de la Complejidad. La Habana: Cátedra; 2014

\section{THE AUTHOR}

Nivaldo Linares Pérez (nlinares@finlay edu.cu), epidemiologist with a master's degree in health sciences and doctorate in collective health, Finlay Vaccine Institute, Havana, Cuba. 